\title{
Main Factors Affecting the Online Shopping of the Large Household Appliances from the e-service Perspective
}

\author{
Chunying Weng \\ Business School, Zhejiang Business Technology Institute, Ningbo, 315016, China \\ 745681944@qq.com
}

\begin{abstract}
As the development of the internet, there are increasingly online shoppers around the world engaging in the e-commerce actives, and more people prefer to buy the large household appliances on line. However, there are few quantitative studies on the investigation of the main affecting factors of the desire to purchase the large household appliances online focused on the market in China, which is one of the developing countries with the highest online population growth. This paper is an attempt to identify the main factors affecting the online shopping of the large household appliances from the e-commerce websites in China, and Fisher's exact test is applied to identify the main affecting factors of online shopping desire. The results could be the guideline for the e-commerce companies in terms of improving their sales of the large household appliances.
\end{abstract}

Keywords: online shopping, Fisher's exact test, empirical study, China

\section{Introduction}

The last decade has seen an exponential increased in commercial use (buying and selling) of Internet because of its convenience of ordering and paying for the products online and have then delivered to the doorstep. Between 2002 and 2012, retail e-commerce grew at 15-25\% per year, following a fairly typical adoption pattern that transformed more mainstream consumers into online shoppers [1]. As one of the developing countries that experience the highest online population growth rates in China. According to a report by the China Internet Network Information Center [2], there are 242 million Internet users engaging in e-commerce activities in China, and the e-commerce market racked up a whopping 190 billion USD worth of transactions in 2012. According to Ystats [3], it is expected to grow by more than 30 percent annually between 2013 and 2016.

In terms of population, China is the largest country in the world, and thus the household appliances are in great demand. However, with the rapidly development of the e-commerce, the online large household appliances (e.g. television, air condition, freezer and washer) shopping is not as popular as the other categories such as fashion, shoes and bags, as well as computers. Morgnaosky and Cude argue that online shoppers are better educated, had relative higher incomes, and tend to be somewhat younger, implying that the online consumers' demand is different from the general populations. It is necessary to identify the main factors effecting consumer willingness to buy online products. However, the related research is still in its infancy [4].

This paper is an attempt to identify the main factors affecting consumers' willingness to buy the large household appliances though the e-commerce websites in China from the eservice perspective, which could be the guideline for the development of these e-commerce companies. The remainder of this study is organized as follows. Section 2 introduces the related literature about the e-commerce. Following is a brief introduction about the Fisher's exact test which is employed in this research. Section 4 discusses the main factors that have an impact on the willingness to buy the online service in China. In the last section, the related managerial implications of this research are discussed. 


\section{Literature Review}

The perceived online service quality and satisfaction are two main characters which are used by consumers to evaluate e-commerce companies' quality. Service quality remains of focal interest to researchers and practitioners. Some researchers consider the delivered service that meet the customer's expectation is the key point. The e-service quality research is still in a primary condition compared with the face-to-face services [5].

A series of researches about web site quality measurement [6,7], online service quality evaluation [8-10], or e-retailing quality appraisal are studied in the related researches. Through three experiments, Moutusy \& Macukh [11] propose that consumers prefer channels with medium (e.g. e-commerce) and high (e.g. in-store) media richness for carrying out complex decision-making tasks and consumers are likely to undertake simple decisionmaking tasks on channels that incorporate low (e.g. m-commerce) levels of media richness.

There are many reasons influencing consumers' decision. Chen \& Xie [12] suggest that user recommendations are critical for consumer purchase decisions and product and product sales. Also, the economic impact of system recommendations has attracted some academic interest. Dellaert \& Haubl [13] identify that system recommendations will influence consumer decision making process. Moreover, Lin [14] presents a model to show that user recommendations are more effective than system recommendations in driving product sales, which demonstrates that not all recommendation types are equally conductive in influencing product sales, suggesting the existence of superior effect are mechanisms for different recommendation types. Especially, a study develops a regression model to capture the differences between online user-created reviews and editor-created reviews in attracting consumers to restaurant webpages.

Zhang et al. [15] find that consumer-created reviews and the volume of these reviews can significantly increase the online popularity of a restaurant, whereas reviews and ratings created by editors have a negative impact on the intention of consumers to visit a restaurant's webpage. For online retails hoping to create a personalized service for a target market, having a good understanding of users' interests has become increasingly important. Nowadays, ecommerce websites can generate tremendous amounts of click-stream data on a daily basis. With such enormous amounts of data becoming available, Su et al. [16] study users' browsing behaviors and their corresponding interest patterns, and find it can be discovered by employing data mining technology. With the growing demand for various varieties of products available all over the world people's expectations are changing for every product.

Dr. B.N. et al. [17] point out that if a company wants to survive in the long run, it should pay special attention to the area of supply chain and logistics. The emergence of modern logistics in e-ecommerce environment makes the logistics in the development of informationization, networking and intelligent direction. Chen \& Lin [18] study that customer loyalty requires a strong desire for a number of factors some of which are based on efficient logistics performance of the company. Another driver is cross-border e-commerce. In this regard, Estrella et al. [19] highlight that distance-related trade costs are greatly reduced compared to offline trade in the same goods. A $1 \%$ increase in the use of efficient and flexible cross-border payment systems could increase cross-border e-commerce by as much as $7 \%$. More and more researches pay attention to the inventory management challenges faced by a B2C e-commerce company. These challenges conclude demand fluctuations which can be caused due to seasonality or product popularity, reverse logistics, stockouts and many more. Harish \& Brig [20] state some suggestions, for instance, being organized, avoiding being out of stock and selecting a particular system or strategy suitable.

\section{Methodology}

Fisher's exact test was first proposed in 1992 [21]. It is a statistical significance test in the analysis of contingency tables, and is suitable for the analysis when some of the frequencies are low and use of the chi-squared test is ruled out (i.e. some expected values are 0 or less 
than twenty percents are less than 5). Fisher's exact test is one of a class of exact tests because the significance of the deviation from a null hypothesis can be calculated exactly, rather than relying on an approximation that becomes exact in the limit as the sample size grows to infinity, as with many statistical tests.

The following is an example to illustrate the theory of the fisher's exact test: a sample of teenagers might be divided into male and female on the one hand, and those that are and are not currently dieting on the other. The hypothesis is that the proportion of dieting individuals is higher among the women than the men, and whether any difference of proportions is significant is tested, and the data is shown as follows:

Table 1. The $2^{\star} 2$ Contingency Table for the Sample

\begin{tabular}{|l|l|l|l|}
\hline & Men & Women & Row total \\
\hline Dieting & 1 & 9 & 10 \\
\hline Non-dieting & 11 & 3 & 14 \\
\hline Column total & 12 & 12 & 24 \\
\hline
\end{tabular}

These data would not be suitable for analysis by Pearson's chi-squared test, because the expected values in the table are all below 10 , and in a $2 * 2$ contingency table, the number of degrees of freedom is always 1.

Before we proceed with the Fisher's exact test, we first introduce some notation. We represent the cells by the letters a, b, c and d, call the totals across rows and columns marginal totals, and represent the grand total by $\mathrm{n}$ :

\section{Table 2. The $2^{\star} 2$ Contingency Table for the Sample with the Representative Letters}

\begin{tabular}{|l|l|l|l|}
\hline & Men & Women & Row total \\
\hline Dieting & $a$ & $b$ & $a+b$ \\
\hline Non-dieting & $c$ & $d$ & $c+d$ \\
\hline Column total & $a+c$ & $b+d$ & $a+b+c+d=n$ \\
\hline
\end{tabular}

The probability of obtaining any such set of values was given by the hypergeometric distribution:

$$
p=\frac{\left(\begin{array}{c}
a+b \\
a
\end{array}\right)\left(\begin{array}{c}
c+d \\
c
\end{array}\right)}{\left(\begin{array}{c}
n \\
a+c
\end{array}\right)}=\frac{(a+b) !(c+d) !(a+c) !(b+d) !}{a ! b ! c ! d ! n !}
$$

Where $\left(\begin{array}{l}n \\ k\end{array}\right)$ is the binomial coefficient and the symbol! Indicates the factorial operator.

$$
p=\frac{\left(\begin{array}{c}
10 \\
1
\end{array}\right)\left(\begin{array}{c}
14 \\
11
\end{array}\right)}{\left(\begin{array}{c}
24 \\
12
\end{array}\right)}=\frac{10 ! 14 ! 12 ! 12 !}{1 ! 9 ! 11 ! 3 ! 24 !} \approx 0.001346076
$$

The formula above gives the exact hypergeometric probability of observing this particular arrangement of the data, assuming the given marginal totals, on the null hypothesis that men and women are equally likely to be dieters. To put it another way, if we assume that the 
probability that a man is a dieter is $\mathrm{p}$, the probability that a woman is a dieter is $p$, and it is assumed that both men and women enter our sample independently of whether or not they are dieters, then this hypergeometric formula gives the conditional probability of observing the values $\mathrm{a}, \mathrm{b}, \mathrm{c}, \mathrm{d}$ in the four cells, conditionally on the observed marginals. This remains true even if men enter our sample with different probabilities than women. The requirement is merely that the two classification characteristics: gender and dieter are not associated.

For example, suppose we knew probabilities $P, Q, p, q$ with $P+Q=p+q=1$ such that (male dieter, male non-dieter, female dieter, female non-dieter) had respective probabilities $(P p, P q, Q p, Q q)$ for each individual encountered under our sampling procedure. The next step is to calculate the exact probability of any arrangement of these teenagers into the four cells of the table, but Fisher's exact test showed that to generate a significance level, we need consider only the cases where the marginal totals are the same as in the observed table, and among those, only the cases where the arrangement is as extreme as the observed arrangement, or more so. In this example, there are 11 such cases. Of these only one is more extreme in the same direction as our data:

Table 3. The $2^{\star} 2$ Contingency Table for the Sample Considering the Marginal Totals

\begin{tabular}{|l|l|l|l|}
\hline & Men & Women & Row total \\
\hline Dieting & 0 & 10 & 10 \\
\hline Non-dieting & 12 & 2 & 14 \\
\hline Column total & 12 & 12 & 24 \\
\hline
\end{tabular}

So the probability is $p=\frac{\left(\begin{array}{c}10 \\ 0\end{array}\right)\left(\begin{array}{l}14 \\ 12\end{array}\right)}{\left(\begin{array}{l}24 \\ 12\end{array}\right)} \approx 0.000033652$

In order to calculate the significance of the observed data, i.e. the total probability of observing data as extreme or more extreme if the null hypothesis is true, we have to calculate the values of $p$ for both these tables, and add them together. This gives a one-tailed test, with $p$ approximately $0.001346076+0.000033652=0.001379728$. This value can be interpreted as the sum of evidence provided by the observed data for the null hypothesis (that there is no difference in the proportions of dieters between men and women). The smaller the value of $p$, the greater the evidence for rejecting the null hypothesis; so here the evidence is strong that men and women are not equally likely to be dieters.

For a two-tailed test we must also consider tables that are equally extreme, but in the opposite direction. An approach used by the Fisher' exact test is to compute the $p$-value by summing the probabilities for all tables with probabilities less than or equal to that of the observed table. In the example here, the 2 -sided p-value is twice the 1-sided value-but in general these can differ substantially for tables with small counts, unlike the case with test statistics that have a symmetric sampling distribution.

\section{Data Collection and Results Analysis}

\subsection{Questionnaire Design}

The specific factors that may have high influence on the consumers' willingness to buy the large household appliances though the e-commerce websites in China from the e-service 
perspective are listed in Table 4. The questionnaire is designed based on these factors, and the respondents are required to evaluate the related situations based on Five-point scale method (1 indicates the worst evaluations, while 5 indicates the best evaluation).

\section{Table 4. The Factors may Have High Influence on the Willingness to Buy the} Large Household Appliances Online

\begin{tabular}{|c|c|l|}
\hline Goal & \multicolumn{1}{|c|}{ Aspects } & Criteria \\
\hline & & $C_{1}$ Efficiency \\
& & $C_{2}$ Ease of navigation \\
& & $C_{3}$ Flexibility \\
Assessment & $A_{1}$ System related & $C_{4}$ Reliability \\
of & & $C_{5}$ Price knowledge \\
willingness & & $C_{6}$ Aesthetics \\
to buy the & & $C_{7}$ Personalization \\
large & & $C_{8}$ Ownership conditions \\
household & & $C_{9}$ Ease of use \\
appliances & & $C_{10}$ Speed \\
online & & $C_{11}$ Responsiveness \\
& & $C_{12}$ Assurance \\
& & $C_{13}$ Delivery \\
& & $C_{14}$ Logistic speed \\
& & $C_{15}$ Customer service \\
& & $C_{16}$ Support cash on delivery \\
& & $C_{17}$ Easy to search \\
& & $C_{18}$ Product Introduction \\
& & $C_{19}$ Loyalty programs \\
\hline
\end{tabular}

Considering the differences among $\mathrm{B} 2 \mathrm{C}, \mathrm{C} 2 \mathrm{C}$ and $\mathrm{B} 2 \mathrm{~B}$ e-commerce, and our research is focus on $\mathrm{B} 2 \mathrm{C}$ e-commerce websites in China, the $9 \mathrm{~B} 2 \mathrm{C}$ e-commerce websites which sell the large household appliances (television, air condition, freezer and washer) in retail market are selected as shown in table 5 .

Table 5. Nine B2C e-commerce Websites in Retail market in China

\begin{tabular}{llc}
\hline No. & E-Commerce Website & No. of users (per million) \\
\hline 1 & Tmall & 9010 \\
2 & Jingdong Mall & 6940 \\
3 & Amazon & 3450 \\
4 & Dangdang & 2160 \\
5 & Suning Mall & 1290 \\
6 & No.1 & 1050 \\
7 & Guomei Mall & 760 \\
8 & Yihaodian & 640 \\
9 & Newegg & 600
\end{tabular}

The respondents are required to identify 1-5 e-commerce websites that they are most familiar with and evaluate the related aspects. In this survey, 50 questionnaires were sent out, 40 were returned and 34 were valid.

\subsection{Internal Consistency Test}

In statistics and research, internal consistency is typically a measure based on the correlations between different items on the same test (or the same subscale on a larger test). It 
measures whether several items that propose to measure the same general construct produce similar scores. Cronbach's $\alpha$ is used to measure the internal consistency of the data in this research. It was first named alpha by Lee Cronbach in 1951, and it is widely used in the social sciences, business, nursing and other disciplines.

Cronbach's $\alpha$ is defined as:

$$
\alpha=\frac{K}{K-1}\left(1-\frac{\sum S_{\mathrm{i}}^{2}}{S_{T}^{2}}\right)
$$

Where $K$ is the number of the components ( $K$-items), $S_{T}^{2}$ is the variance of the observed total test scores, and $S_{i}^{2}$ is the variance of component $i$ for the current samples.

The Cronbach's $\alpha$ is 0.6381 in this research which means that the internal consistency is acceptable.

\subsection{Fisher's Exact Test}

The service related factors are taken for example to show the Fisher's exact test, and the hypotheses and the Fisher's exact test process related with system related factors are as follows:

Hypothesis-1(a): Responsiveness (C11) has a significant influence on the sales of the large household appliances

Hypothesis-1(b): Responsiveness (C11) has a lower influence on the sales of the large household appliances

\section{Table 6. Sales* Responsiveness (C11) Impact Analysis}

\begin{tabular}{|c|c|c|c|c|}
\hline \multicolumn{5}{|c|}{ Chi-Square Tests } \\
\hline & Value & df & $\begin{array}{l}\text { Asymp. Sig. (2- } \\
\text { sided) }\end{array}$ & $\begin{array}{l}\text { Exact Sig. (2- } \\
\text { sided) }\end{array}$ \\
\hline Pearson Chi-Square & $13.992 \mathrm{a}$ & 4 & .007 & .004 \\
\hline Likelihood Ratio & 16.565 & 4 & .002 & .003 \\
\hline Fisher's Exact Test & 11.968 & & & .004 \\
\hline $\mathrm{N}$ of Valid Cases & 34 & & & \\
\hline
\end{tabular}

a. 7 cells $(70.0 \%)$ have expected count less than 5 . The minimum expected count is .47 .

As shown in Table 6,the value of Fisher's Exact Test is 11.968,Exact Sig.(2-sided) is 0.003 , which is lower than 0.05 , therefore Hypothesis-1(a)is accepted with significant level of $5 \%$, which means that responsiveness has a significant influence on online sales of the large household appliances .

Hypothesis-2(a): Assurance (C12) has a significant influence on the sales of the large household appliances

Hypothesis-2(b): Assurance (C12) has a lower influence on the sales of the large household appliances

Table 7. Sales* Assurance (C12) Impact Analysis

\begin{tabular}{|c|c|c|c|c|}
\hline \multicolumn{5}{|c|}{ Chi-Square Tests } \\
\hline & Value & df & $\begin{array}{l}\text { Asymp. Sig. (2- } \\
\text { sided) }\end{array}$ & $\begin{array}{l}\text { Exact Sig. (2- } \\
\text { sided) }\end{array}$ \\
\hline Pearson Chi-Square & $13.234 \mathrm{a}$ & 8 & .104 & .097 \\
\hline Likelihood Ratio & 13.195 & 8 & .105 & .186 \\
\hline Fisher's Exact Test & 11.106 & & & .112 \\
\hline $\mathrm{N}$ of Valid Cases & 34 & & & \\
\hline
\end{tabular}




\begin{tabular}{|c|c|c|c|c|}
\hline \multicolumn{5}{|c|}{ Chi-Square Tests } \\
\hline & Value & df & $\begin{array}{l}\text { Asymp. Sig. (2- } \\
\text { sided) }\end{array}$ & $\begin{array}{l}\text { Exact Sig. (2- } \\
\text { sided) }\end{array}$ \\
\hline Pearson Chi-Square & $13.234 \mathrm{a}$ & 8 & .104 & .097 \\
\hline Likelihood Ratio & 13.195 & 8 & .105 & .186 \\
\hline Fisher's Exact Test & 11.106 & & & .112 \\
\hline
\end{tabular}

a. 13 cells $(86.7 \%)$ have expected count less than 5 . The minimum expected count is .29 .

As shown in Table 7,the value of Fisher's Exact Test is 11.106,Exact Sig.(2-sided) is 0.112 , which is higher than 0.05 ,therefore Hypothesis-2(a)is rejected with significant level of $5 \%$,which means that assurance has a lower influence on online sales of the large household appliances .

Hypothesis-3(a): Delivery (C13) has a significant influence on the sales of the large household appliances

Hypothesis-3(b): Delivery (C13) has a lower influence on the sales of the large household appliances

Table 8. Sales* Delivery (C13) Impact Analysis

\begin{tabular}{|c|c|c|c|c|}
\hline \multicolumn{5}{|c|}{ Chi-Square Tests } \\
\hline & Value & $\mathrm{df}$ & $\begin{array}{l}\text { Asymp. Sig. (2- } \\
\text { sided) }\end{array}$ & $\begin{array}{l}\text { Exact Sig. (2- } \\
\text { sided) }\end{array}$ \\
\hline Pearson Chi-Square & $9.019 \mathrm{a}$ & 4 & .061 & .054 \\
\hline Likelihood Ratio & 11.868 & 4 & .018 & .034 \\
\hline Fisher's Exact Test & 8.568 & & & .052 \\
\hline $\mathrm{N}$ of Valid Cases & 34 & & & \\
\hline
\end{tabular}

a. 8 cells $(80.0 \%)$ have expected count less than 5 . The minimum expected count is .82 .

As shown in Table 8,the value of Fisher's Exact Test is 11.868,Exact Sig.(2-sided) is 0.052 , which is lower than 0.05 , which is higher than 0.05 ,therefore Hypothesis-3(a)is rejected with significant level of $5 \%$

Hypothesis-4(a): Logistic speed (C14) has a significant influence on the sales of the large household appliances

Hypothesis-4(b): Logistic speed (C14) has a lower influence on the sales of the large household appliances

Table 9. Sales* Logistic Speed (C14) Impact Analysis

\begin{tabular}{|c|c|c|c|c|}
\hline \multicolumn{5}{|c|}{ Chi-Square Tests } \\
\hline & Value & df & $\begin{array}{l}\text { Asymp. Sig. (2- } \\
\text { sided) }\end{array}$ & $\begin{array}{l}\text { Exact Sig. (2- } \\
\text { sided) }\end{array}$ \\
\hline Pearson Chi-Square & $8.237 \mathrm{a}$ & 4 & .083 & .078 \\
\hline Likelihood Ratio & 9.078 & 4 & .059 & .100 \\
\hline Fisher's Exact Test & 7.356 & & & .097 \\
\hline $\mathrm{N}$ of Valid Cases & 34 & & & \\
\hline
\end{tabular}

a. 8 cells $(80.0 \%)$ have expected count less than 5 . The minimum expected count is .76 .

As shown in Table 9,the value of Fisher's Exact Test is 7.356,Exact Sig.(2-sided) is 0.097, which is higher than 0.05,therefore Hypothesis-4(a)is rejected with significant level of $5 \%$.

Hypothesis-5(a): Customer service (C15) has a significant influence on the sales of the large household appliances 
Hypothesis-5(b): Customer service (C15) has a lower influence on the sales of the large household appliances

Table 10. Sales* Customer Service (C15) Impact Analysis

\begin{tabular}{|c|c|c|c|c|}
\hline \multicolumn{5}{|c|}{ Chi-Square Tests } \\
\hline & Value & df & $\begin{array}{l}\text { Asymp. Sig. (2- } \\
\text { sided) }\end{array}$ & $\begin{array}{l}\text { Exact Sig. (2- } \\
\text { sided) }\end{array}$ \\
\hline Pearson Chi-Square & $10.690 \mathrm{a}$ & 4 & .030 & .021 \\
\hline Likelihood Ratio & 11.926 & 4 & .018 & .034 \\
\hline Fisher's Exact Test & 9.687 & & & .030 \\
\hline $\mathrm{N}$ of Valid Cases & 34 & & & \\
\hline
\end{tabular}

a. 8 cells $(80.0 \%)$ have expected count less than 5 . The minimum expected count is .82 .

As shown in Table 10,the value of Fisher's Exact Test is 9.687,Exact Sig.(2-sided) is 0.030 , which is lower than 0.05 ,therefore Hypothesis-5(a)is accepted with significant level of $5 \%$, which means that customer service has a significant influence on online sales of the large household appliances .

Hypothesis-6(a): Support cash on delivery (C16) has a significant influence on the sales of the large household appliances

Hypothesis-6(b): Support cash on delivery (C16) has a lower influence on the sales of the large household appliances

\section{Table 11. Sales* Support Cash on Delivery (C16) Impact Analysis}

\begin{tabular}{|c|c|c|c|c|}
\hline \multicolumn{5}{|c|}{ Chi-Square Tests } \\
\hline & Value & df & $\begin{array}{l}\text { Asymp. Sig. (2- } \\
\text { sided) }\end{array}$ & $\begin{array}{l}\text { Exact Sig. (2- } \\
\text { sided) }\end{array}$ \\
\hline Pearson Chi-Square & $4.745 \mathrm{a}$ & 8 & .784 & .839 \\
\hline Likelihood Ratio & 6.121 & 8 & .634 & .812 \\
\hline Fisher's Exact Test & 4.674 & & & .871 \\
\hline $\mathrm{N}$ of Valid Cases & 34 & & & \\
\hline
\end{tabular}

a. 13 cells $(86.7 \%)$ have expected count less than 5 . The minimum expected count is .24 .

As shown in Table 11,the value of Fisher's Exact Test is 4.674,Exact Sig.(2-sided) is 0.871 , which is higher than 0.05 , therefore Hypothesis-6(a) is rejected with significant level of $5 \%$.

Hypothesis-7(a): Easy to search (C17) has a significant influence on the sales of the large household appliances

Hypothesis-7(b): Easy to search $(\mathrm{C} 17)$ has a lower influence on the sales of the large household appliances

\section{Table 12. Sales* Easy to Search (C17) Impact Analysis}

\begin{tabular}{|c|c|c|c|c|}
\hline \multicolumn{5}{|c|}{ Chi-Square Tests } \\
\hline & Value & $\mathrm{df}$ & $\begin{array}{l}\text { Asymp. Sig. (2- } \\
\text { sided) }\end{array}$ & $\begin{array}{l}\text { Exact Sig. (2- } \\
\text { sided) }\end{array}$ \\
\hline Pearson Chi-Square & $29.727 \mathrm{a}$ & 8 & .000 & .001 \\
\hline Likelihood Ratio & 22.851 & 8 & .004 & .003 \\
\hline Fisher's Exact Test & 16.233 & & & .008 \\
\hline $\mathrm{N}$ of Valid Cases & 34 & & & \\
\hline
\end{tabular}

a. 14 cells $(93.3 \%)$ have expected count less than 5 . The minimum expected count is .18 . 
As shown in Table 12,the value of Fisher's Exact Test is 16.233,Exact Sig.(2-sided) is 0.008 ,which is lower than 0.05,therefore Hypothesis-7(a)is accepted with significant level of $5 \%$, which means that easy to search has a significant influence on online sales of the large household appliances .

Hypothesis-8(a): Product Introduction (C18) has a significant influence on the sales of the large household appliances

Hypothesis-8(b): Product Introduction (C18) has a lower influence on the sales of the large household appliances

Table 13. Sales* Product Introduction (C18) Impact Analysis

\begin{tabular}{|c|c|c|c|c|}
\hline \multicolumn{5}{|c|}{ Chi-Square Tests } \\
\hline & Value & df & $\begin{array}{l}\text { Asymp. Sig. (2- } \\
\text { sided) }\end{array}$ & $\begin{array}{l}\text { Exact Sig. (2- } \\
\text { sided) }\end{array}$ \\
\hline Pearson Chi-Square & $7.572 \mathrm{a}$ & 4 & .109 & .101 \\
\hline Likelihood Ratio & 8.651 & 4 & .070 & .100 \\
\hline Fisher's Exact Test & 6.910 & & & .117 \\
\hline $\mathrm{N}$ of Valid Cases & 34 & & & \\
\hline
\end{tabular}

a. 9 cells $(90.0 \%)$ have expected count less than 5. The minimum expected count is .94 .

As shown in Table 13, the value of Fisher's Exact Test is 6.910,Exact Sig.(2-sided) is 0.117 , which is higher than 0.05 ,therefore Hypothesis-8(a)is rejected with significant level of $5 \%$.

Hypothesis-9(a): Loyalty Program (C19) has a significant influence on the sales of the large household appliances

Hypothesis-9(b): Loyalty Program (C19) has a lower influence on the sales of the large household appliances

Table 14. Sales* Loyalty Program (C19) Impact Analysis

\begin{tabular}{|c|c|c|c|c|}
\hline \multicolumn{5}{|c|}{ Chi-Square Tests } \\
\hline & Value & $\mathrm{df}$ & $\begin{array}{l}\text { Asymp. Sig. (2- } \\
\text { sided) }\end{array}$ & $\begin{array}{l}\text { Exact Sig. (2- } \\
\text { sided) }\end{array}$ \\
\hline Pearson Chi-Square & $27.828 \mathrm{a}$ & 12 & .006 & .004 \\
\hline Likelihood Ratio & 28.199 & 12 & .005 & .008 \\
\hline Fisher's Exact Test & 20.245 & & & .009 \\
\hline $\mathrm{N}$ of Valid Cases & 34 & & & \\
\hline
\end{tabular}

a. 20 cells $(100.0 \%)$ have expected count less than 5 . The minimum expected count is .29 .

As shown in Table 14,the value of Fisher's Exact Test is 20.245,Exact Sig.(2-sided) is 0.009 , which is lower than 0.05,therefore Hypothesis-9(a)is accepted with significant level of $5 \%$.

\section{Conclusions}

This paper is an attempt to identify the main factors affecting consumers' willingness to buy the large household appliances though the e-commerce websites in China from the eservice perspective, which could be the guideline for the development of these e-commerce companies. The primary data for this research are collected through a questionnaire, and Fisher's exact test is applied to identify the criteria of online sales of the large household appliances impact analysis. 
According to the results of the analysis, the main factors affecting consumers' willingness to buy the large household appliances though the e-commerce websites in China are shown in Table 15:

\section{Table 15. The Analysis Result of the Main Factors Affecting Online Sale of the Large Household Appliances}

\begin{tabular}{|c|l|l|}
\hline \multicolumn{1}{|c|}{ Aspect } & \multicolumn{1}{|c|}{ Main factor } & \multicolumn{1}{c|}{ Exact Sig. (2-sided) } \\
\hline \multirow{3}{*}{$A_{1}$ System related } & $C_{1}$ Efficiency & 0.000 \\
& $C_{2}$ Ease of navigation & 0.003 \\
& $C_{3}$ Flexibility & 0.007 \\
\hline \multirow{4}{*}{$A_{2}$ Service related } & $C_{11}$ Responsiveness & 0.004 \\
& $C_{15}$ Customer service & 0.030 \\
& $C_{17}$ Easy to search & 0.008 \\
& $C_{19}$ Loyalty program & 0.009 \\
\hline
\end{tabular}

Based on the results of this research, our recommendations for improving the online service of the e-commerce companies are: (1) improving the efficiency, flexibility and ease of navigation; (2) shortening the response time; and (3) enriching loyalty program and customer service.

\section{Acknowledgments}

It is a project supported by Soft Scientific Research Project of Ningbo under 2014A10023, Philosophy and Social Sciences Planning Project of Zhejiang Province under 12JCJJ11YB and Soft Scientific Research Project of Zhejiang Province under 2014C35021.

\section{References}

[1] P. Jing and K. B. Siva, "An empirical comparison of market efficiency: Electronic marketplaces vs. traditional retail formats", Electronic Commerce Research and Applications, vol. 13, (2014), pp. 98-109.

[2] CNNIC, "China's online shopping market research report", http://tech.sina.com.cn/i/ 2013-0416/13328244628.shtml, (2013).

[3] Ystats, "China B2C E-Commerce Report", http://ystats.com, (2013).

[4] M. Howard and C. Worboys, "Self-service - a contradiction in terms or customer-led choice?", Journal Consume Behavior, vol. 2, no. 4, (2003), pp. 382-92.

[5] A. Serkan, A. Eda and A. Safak, "Re-assessment of E-S-Qual and E-RecS-Qual in a pure service setting", Journal of Business Research, vol. 63, no. 3, (2010), pp. 232-240.

[6] E. T. Loiacono, R. T. Watson and D. L. Hoodhue, "WEBQUAL:measure of website quality", Marketing Educators Conference: Marketing Theory and Applications, vol. 13, (2002), pp. 432-437.

[7] B. Yoo and N. Donthu, "Developing a scale to measure the perceived quality of Internet shopping sites (SITEQUAL)", Quarterly Journal of Electronic Commerce, vol. 2, no. 1, (2001), pp. 31-47.

[8] H. H. Bauer, T. Falk and M. Hammerschmidt, "E Trans Qual:a transaction process-based approach for capturing service quality in online shopping", Journal of Business Research, vol. 59, (2006), pp. 866-875.

[9] A. Parasuraman, V. A. Zeithaml and A. Malhotra, "E-S-Qual: a multiple-item scale for assessing electronic service quality", Journal of Service Research, vol. 7, no. 3, (2005), pp. 213-233.

[10] V. A. Zeithaml, A. Parasuraman and A. Malhotra, "E-service quality: definition, dimensions and conceptual model", Working Paper, Marketing Science Institute, (2000).

[11] M. Moutusy and D. Mayukh, "Consumer decision-making across modern and traditional channels: Ecommerce, m-commerce, in-store”, Decision Support Systems, vol. 61, (2014), pp. 34-46.

[12] Y. B. Chen and J. H. Xie, "Online Consumer Review: Word-of-Mouth as a New Element of Marketing Communication Mix”, Management Science, vol. 54, no. 3, (2008), pp. 477-491.

[13] B. G. Dellaert and G. Haubl, "Searching in choice mode: consumer decision processes in product search with recommendations", Journal of Marking Research, vol. 49, no. 2, (2012), pp. 277-288.

[14] Z. J. Lin, "An empirical investigation of user and system recommendations in e-commerce", Decision Support Systems, Press, (2014).

[15] Z. Q. Zhang, Q. Ye, L. Rob and Y. J. Li, "The impact of e-word-of-mouth on the online popularity of restaurants: A comparison of consumer reviews and editor reviews", International Journal of Hospitality Management, vol. 29, (2010), pp. 694-700. 
[16] Q. Su and L. Chen, "A method for discovering clusters of e-commerce interest patterns using click-stream data", Electronic Commerce Research and Applications, Press, (2014).

[17] B. N., M. M. and A. T., "Supply chain and logistics for the present day business", Procedia Economics and Finance, vol. 11, (2014), pp. 665-675.

[18] X. L. Chen and H. Lin, "Research on e-commerce logistics system informationization in chain", ProcediaSocial and Behavioral Sciences, vol. 96, (2013), pp. 838-843.

[19] G. H. Estrella, M. Bertin and T. Geomina, "The drivers and impediments for cross-border e-commerce in the EU”, Information Economics and Policy, vol. 28, (2014), pp. 83-96.

[20] P. Harish and R. D. Brig, "Inventory management challenges for B2C E-Commerce retailers", Procedia Economics and Finance, vol. 11, (2014), pp. 561-571.

[21] R. A. Fisher, "On the interpretation of $\chi^{2}$ from contingency tables, and the calculation of P", Journal of the Royal Statistical Society, vol. 85, no. 1, (1922), pp. 87-94.

\begin{abstract}
Author
Chunying Weng, she received her M.Sc. in International Business (2009) from Nottingham University. Now she is working at Business School, Zhejiang Business Technology Institute. Her current research interests include different aspects of E-commerce and service economy.
\end{abstract}

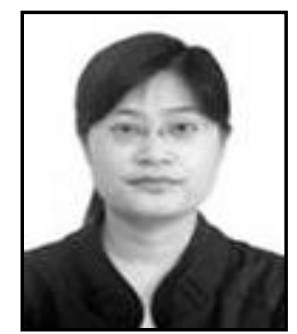


International Journal of $u-$ and $e-$ Service, Science and Technology Vol.8, No.5 (2015) 